\title{
Young Salers suckled bull production: effect of diet on performance, carcass and muscle characteristics and meat quality
}

\author{
E. Serrano, P. Pradel, R. Jailler, H. Dubroeucq, D. Bauchart, J.-F. Hocquette, A. Listrat, \\ J. Agabriel and D. Micol ${ }^{\dagger}$
}

INRA-Theix, 63122 Saint-Genès-Champanelle, France

(Received 12 May 2006; Accepted 9 March 2007)

\begin{abstract}
The aim of this work was to improve the knowledge on young suckled Salers bull production and to study the effect of forage type and concentrate level on performance, carcass and muscle characteristics as well as on meat quality. Twenty-four Salers male calves of 150 days of age were assigned to six groups: CO (fed exclusively with hay and dam's milk and slaughtered at approximately 6 months of age), and HH (hay - high concentrate), HL (hay - low concentrate), GH (cut grass - high concentrate), GL (cut grass - low concentrate) and CP (control pasture: pasture - high concentrate) groups differing in feeds received until slaughter and slaughtered unweaned at approximately 10 months of age. Carcass weights averaged $210 \mathrm{~kg}$ at 10 months of age at slaughter. Average daily weight gain (ADWG) in HH and GH groups tended to be higher $(P=0.09)$ than in $H L$ and GL groups (1354 v. $1248 \mathrm{~g} /$ day). ADWG in CP group $(1542 \mathrm{~g} /$ day) was higher $(\mathbb{P}<0.05)$ than in the other groups. Carcass weight in $C P$ group $(230 \mathrm{~kg})$ tended to be higher $(\mathbb{P}<0.1)$ than in $\mathrm{HL}(198 \mathrm{~kg})$ and $\mathrm{GL}(200 \mathrm{~kg})$ groups. Carcass muscle weight was higher $(\mathrm{P}<0.05)$ in $\mathrm{GH}(155 \mathrm{~kg})$ and $\mathrm{CP}$ groups $(165 \mathrm{~kg})$ than in $\mathrm{HL}(141 \mathrm{~kg})$ and $\mathrm{GL}(142 \mathrm{~kg})$ groups. Carcass and offal fatty tissue weights and carcass fatness did not differ between groups. Neither forage type nor concentrate level had significant effect on the area of muscle fibres or on muscle metabolic enzyme activities (namely, lactate dehydrogenase - LDH, phosphofructokinase - PFK, isocitrate dehydrogenase - ICDH, citrate synthase - CS and cytochrome-c oxidase - COX). semitendinosus muscle of CP group presented higher CS enzyme activities $(8.10 \mu \mathrm{mol} / \mathrm{min} \mathrm{per} \mathrm{g})$ than $\mathrm{HH}(5.30 \mu \mathrm{mol} / \mathrm{min} \mathrm{per}$ g) and GL $(4.52 \mu \mathrm{mol} / \mathrm{min}$ per $\mathrm{g})$ groups. Neither total nor insoluble collagen content significantly differed between groups. Lipid content in rectus abdominis muscle was relatively low (average $67.5 \mathrm{mg} / \mathrm{g}$ dry matter) and was not affected by diet $(\mathrm{P}>0.05)$. The ratio between $\mathrm{n}-6$ and $\mathrm{n}-3$ polyunsaturated fatty acid content was lower $(\mathrm{P}=0.01)$ in the low-concentrate-fed than in the high-concentrate-fed group (3.95 v. 5.37, respectively). Sensory analysis noted that longissimus thoracis muscle from $C P$ animals was more tender and juicy than that from $H H$ and $G H$ animals $(P<0.05)$.
\end{abstract}

Keywords: carcass, concentrates, forage type, meat quality, suckled bulls

\section{Introduction}

In the mountain regions of France, most male calves produced from beef herds are sold lean at weaning, i.e. between 8 and 10 months of age (as 'broutards'), to be finished elsewhere. In these areas, since the imposition of Common Agricultural Policy measures, dairy or mixed cow herds have frequently been replaced by suckler herds. In several areas of European Mediterranean countries, beef obtained from young bulls less than 1 year of age represents an important percentage of beef consumption

\footnotetext{
${ }^{\dagger}$ E-mail: micol@clermont.inra.fr
}

(Chatellier et al., 2003). Production of 'finished broutards' could thus represent an interesting possibility to enhance the profitability of mountain farms.

Salers is a dual-purpose breed used for beef production in mountainous areas of central France whose medium precocity characteristics and relatively high milking potential (D'Hour et al., 1995 and 1996; Liénard et al., 2002) may be especially adequate for this type of production based on relatively young animals suckled until slaughter.

Many factors influence animal performance, carcass characteristics and meat quality. However, diet and, especially, forage type and concentrate level, are among the most important factors (Listrat et al., 1999; Geay et al., 
Young Salers suckled bull production

2002; Nuernberg et al., 2005). The effects of forage type and concentrate level used in different periods of production have previously been studied, but little information is available for young bulls (slaughtered between 10 and 12 months of age) suckled until slaughter. Therefore, the aims of this work were to examine the effect of diet (type of forage and level of concentrate) on performance, carcass and muscle characteristics as well as on meat quality of young suckled Salers bulls.

\section{Material and methods}

\section{Animals and experimental design}

This study was conducted at the experimental farm of INRA Marcenat (Cantal, France). Twenty-four winter-born (4 January \pm 16.7 days) Salers male calves were used. All animals were reared indoors by the conventional winter calf-rearing procedure of French mountain zones until approximately 150 days of age: they were suckled twice a day by their dams, having free access to medium-quality cocksfoot hay. On turn-out to pasture (24 May) animals were randomly assigned to six groups according to diet and slaughter age: CO (control) fed exclusively with winter diet and slaughtered at approximately 6 months of age (used as point 0 in carcass composition estimations explained below) and $\mathrm{HH}, \mathrm{HL}, \mathrm{GH}, \mathrm{GL}$ and $\mathrm{CP}$ groups offered ad libitum cocksfoot hay plus concentrate and slaughtered at approximately 10 months of age $(\mathrm{HH}$, hay - high concentrate) or in a quantity equivalent to half of ad libitum group (HL, hay - low concentrate); ad libitum cut grass plus concentrate ( $\mathrm{GH}$, grass - high concentrate) or in a quantity equivalent to half of ad libitum group (GL, grass - low concentrate); and ad libitum grazed highland grass and ad libitum concentrate ( $\mathrm{CP}$, control pasture) group.

$\mathrm{HH}, \mathrm{HL}, \mathrm{GH}$ and $\mathrm{GL}$ animals were housed in individual pens and feeds were offered once a day and individual intakes were recorded 5 days/week. They were suckled twice a day by their dams throughout the experimental period and the cows' diet consisted of cocksfoot hay for dams of $\mathrm{HH}$ and $\mathrm{HL}$ animals and grazed grass for dams of $\mathrm{GH}$ and $\mathrm{GL}$ animals. Grass offered to $\mathrm{GH}$ and GL groups was green vegetative herbage (spring growths and summer regrowths) from a natural pasture cut every morning. The CP group remained on pasture (1100 m in altitude) with their mothers; they grazed in a continuous system of high diversity of natural pasture and were offered concentrate ad libitum as a group. Table 1 shows species composition (expressed as percentage) of parcel pastured by CP group and parcel used to obtain cut grass for GH and GL groups.

All animals were individually weighed once a week before and after suckling in order to estimate milk ingestion and live weight (Le Neindre, 1973). Calves were weighed in the early morning before feed distribution. CP calves rested in the same pasture but separated from their mothers during the night before weighing. Average daily gain was calculated by linear regression. Concentrate composition
Table 1 Relative presence of species (\%) of parcel pastured by group $\mathrm{CP}$ and parcel used to obtain cut grass for groups $\mathrm{GH}$ and $\mathrm{GL}^{+}$

\begin{tabular}{|c|c|c|c|}
\hline CP group parcel & $\%$ & GH and GL groups parcel & $\%$ \\
\hline \multicolumn{4}{|l|}{ Dicotyledons } \\
\hline Plantago lanceolata & 8.6 & Taraxacum gr. officinale & 19.6 \\
\hline Trifolium repens & 5.6 & Capsella bursa-pastoris & 2.8 \\
\hline Achillea millefolium & 5.0 & Rumex obtusifolius & 2.2 \\
\hline Campanula glomerata & 3.3 & Veronica chamaedrys & 1.7 \\
\hline Ranunculus acris & 3.1 & Stellaria media & 1.7 \\
\hline Rhinantus minor & 2.8 & Veronica arvensis & 0.6 \\
\hline Galium verum & 2.5 & Cerastium fontanum & 0.6 \\
\hline Taraxacum gr. officinale & 2.2 & & \\
\hline Lotus corniculatus & 1.9 & & \\
\hline Ranunculus bulbosus & 1.9 & & \\
\hline Polygonum bistorta & 1.7 & & \\
\hline Stachys officinalis & 1.7 & & \\
\hline Trifolium pratense & 1.5 & & \\
\hline Thymus pulegioides & 1.4 & & \\
\hline Sanguisorba minor & 1.1 & & \\
\hline Trifolium dubium & 1.0 & & \\
\hline Rumex acetosa & 0.6 & & \\
\hline Veronica chamaedrys & 0.6 & & \\
\hline Cerastium arvense & 0.3 & & \\
\hline Meum athamanticum & 0.3 & & \\
\hline Stellaria graminea & 0.3 & & \\
\hline \multicolumn{4}{|l|}{ Monocotyledons } \\
\hline Agrostis sp. & 15.6 & Dactylis glomerata & 19.0 \\
\hline Festuca nigrescens & 10.0 & Lolium perenne & 15.6 \\
\hline Avenula pubescens & 7.0 & Agrostis capillaris & 13.4 \\
\hline Poa trivialis & 3.5 & Trisetum flavescens & 9.5 \\
\hline Antoxamtum odoratum & 3.1 & Bromus mollis & 6.7 \\
\hline Phleum pratense & 2.8 & Arrhenatherum elatius & 3.4 \\
\hline Cynosurus cristatus & 2.5 & Poa trivalis & 1.6 \\
\hline Carex caryophyllea & 1.9 & Poa pratensis & 0.6 \\
\hline Avenula pratensis & 1.9 & Holcus mollis & 0.6 \\
\hline Poa pratensis & 1.5 & Phleum pratense & 0.6 \\
\hline Trisetum flavescens & 1.1 & & \\
\hline Festuca rubra & 1.1 & & \\
\hline Koeleria pyramidata & 0.6 & & \\
\hline Luzula campestris & 0.3 & & \\
\hline
\end{tabular}

${ }^{\dagger}$ Abbreviations are: $\mathrm{CP}=$ control pasture; $\mathrm{GH}=$ cut grass - high concentrate; $\mathrm{GL}=$ cut grass - low concentrate.

and feed values are given in Tables 2 and 3, respectively. Water and salt blocks were always available to animals.

\section{Slaughter procedure}

Animals were slaughtered at the experimental slaughterhouse at INRA, Centre of Clermont Ferrand-Theix (Puy de Dôme, France) in five batches: 1 July for $\mathrm{CO}$ group animals and between 4 October and 8 November for the other groups. In each slaughter batch, the oldest animals in each group were slaughtered first. On the day of slaughter, animals were weighed in the early morning, transported $90 \mathrm{~km}$ to the slaughter facility and slaughtered at random within $4 \mathrm{~h}$ of removal from experimental farm. Carcasses 
Table 2 Concentrate composition

\begin{tabular}{lc}
\hline \hline Concentrate ingredients & $\mathrm{g} / \mathrm{kg}$ of dry matter \\
\hline Wheat & 330 \\
Soya-bean meal & 210 \\
Maize feed & 200 \\
Wheat bran & 100 \\
Dried sugar-beet pulp & 90 \\
Sugar-beet molasses & 28 \\
Vegetal fats & 27 \\
Mineral-vitamin supplement & 15 \\
\hline \hline
\end{tabular}

were visually graded according to SEUROP beef carcass grading system for conformation (scale ranging from 18 $(\mathrm{S}+$, very good, superior, conformation) to $1(\mathrm{P}-$, very poor conformation)) and fatness (scale ranging from 5 (very $2 \mathrm{~h}$, then in a refrigerated room set to $4^{\circ} \mathrm{C}$ until $24 \mathrm{~h}$ post mortem. After a $2 \mathrm{~h}$ chilling, subjective lean colour was carcass classification ranging from $1=$ white to $4=$ red. $\mathrm{pH}$ of semitendinosus (ST) and rectus abdominis (RA) muscles were measured $24 \mathrm{~h}$ post mortem. Colorimetric parameters of the CIE $L^{*} a^{*} b^{*}$ uniform colour space (Commission International de l'Eclairage, 1986) were measured on ST and

\section{Body composition}

The empty body weight, hot carcass weight, and weights of the metacarpus bones and the offal fatty tissues (kidney, heart and digestive tract) were measured. On the following day, the left half carcass of each animal was quartered between the 5th and 6th thoracic vertebrae and the 6th rib was extracted (as described by Robelin and Geay, 1975), weighed and dissected into lean tissue, fat and bone. Two days after slaughter, the right half carcasses of 14 animals (four CO animals plus two animals of each of the other experimental groups) were dissected and the total weights of lean, bone and fat were recorded according to anatomical distribution.

Regression analysis was used to relate carcass composition traits (muscle, fatty tissues and bone weights) obtained from dissection of right half carcass of 14 animals with the predictors obtained from the dissection of 6th rib, metacarpus bone weight and carcass weight of these animals (Robelin and Geay, 1975). The regression analyses were performed using the GLM procedure of the Statistical Analysis Systems Institute (SAS, 1989) and independent variables were selected by stepwise method. Muscle, fat and bone carcass weights of all experimental animals were estimated using these equations. Total body fat was calculated as the sum of recorded kidney, heart and digestive tract fatty tissues and carcass fat estimated by linear regression. high) to 1 (very low)) and placed at room temperature for judged by an experienced person using a scale used for veal RA muscles using a MINOLTA CM 2002 recording spectrocolorimeter (illuminant D65, observer angle $10^{\circ}$ ).

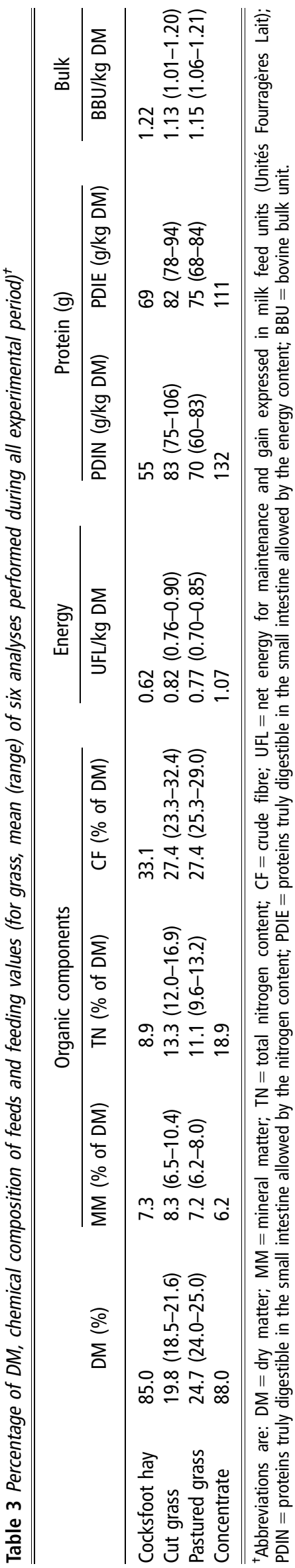




\section{Muscle characteristics}

Two samples of ST and RA muscles of each animal were taken $1 \mathrm{~h}$ after slaughter for the determination of muscle fibre size and metabolic enzyme activities. Collagen and lipid contents were determined only in RA muscle samples. The epimysium was carefully dissected and about $300 \mathrm{~g}$ of muscle was taken. Part of each sample was frozen in isopentane, chilled in liquid nitrogen for fibre size determination and a further portion was directly frozen in liquid nitrogen and kept at $-80^{\circ} \mathrm{C}$ until analysed for enzyme activities determination. In the case of RA muscle, the rest of the sample was cut in pieces ( 1 to $2 \mathrm{~cm}$ cross section), sealed under vacuum and stored at $-20^{\circ} \mathrm{C}$ until analysed for collagen and lipid content.

\section{Muscle fibre size}

Serial sections of $10-\mu \mathrm{m}$ thick RA and ST muscles were cut on a cryostat at $-25^{\circ} \mathrm{C}$, perpendicular to the muscle fibres. The cells were stained with azorubine to define their outline and their mean surface areas were measured in two randomly selected areas of serial sections with an image analysis software program (Visilog, INRA, France) (Jurie et al., 1998). An average of 100 fibres were analysed on each serial section.

\section{Metabolic enzyme activities}

RA and ST muscle samples were ground and homogenised in $140 \mathrm{mmol} / / \mathrm{l}$ sucrose and $50 \mathrm{mmol} / \mathrm{l}$ triethanolamine buffer $\left(\mathrm{pH} \mathrm{7.5)}\right.$ and centrifuged at $6000 \times \mathbf{g}$ for $15 \mathrm{~min}$ at $4^{\circ} \mathrm{C}$. Enzyme activities were measured in the supernatant. Anaerobic glycolytic metabolism was assessed by lactate dehydrogenase (LDH) and phosphofructokinase (PFK) activities (Beutler, 1971; Brandstetter et al., 1998). Aerobic oxidative metabolism was studied by measuring isocitrate dehydrogenase (ICDH), citrate synthase (CS) and cytochrome-c oxidase (COX) activities (Brandstetter et al., 1998; Piot et al., 1998). Enzyme activities were expressed in $\mu \mathrm{mol} / \mathrm{min}$ per gram of wet muscle.

\section{Collagen}

Total hydroxyproline (OH-Prol) content and collagen in the insoluble part were measured as described by Listrat et al. (1999 and 2001). Data are presented as means of triplicate measurements and are expressed, for total and insoluble collagen, in $\mu \mathrm{g} \mathrm{OH}$-Prol per mg of dry matter (DM) and also as percentage of $\mathrm{OH}$-Prol in the soluble part per total amount of $\mathrm{OH}-\mathrm{Prol}$.

\section{Lipids}

Total lipids of RA muscle were extracted according to the method of Folch et al. (1957), vacuum dried and weighed. They were solubilised into $5 \mathrm{ml}$ chloroform. Fatty acids from total lipids were esterified in boron-trifluoride/methanol as described by Glass (1971). The fatty acid composition was determined by gas-liquid chromatography, using a chromatograph DELSI DI 200, a flame ionisation detector, a 100-m long CP-Sil 88 (Varian) glass capillary column and $\mathrm{H}_{2}$ as the gas vector as described by Aurousseau et al. (2004).

\section{Sensory assessment}

Seventh to 11 th ribs were taken $24 \mathrm{~h}$ after slaughter from the left side of carcass. Samples were placed in sealed plastic bags under vacuum and kept at $4^{\circ} \mathrm{C}$ for 8 days for ageing and then frozen at $-20^{\circ} \mathrm{C}$ until analysis. After thawing, ribs were cooked in a double sided grill $\left(280^{\circ} \mathrm{C}\right)$ for $2 \mathrm{~min}$ and $30 \mathrm{~s}$. Cooked longissimus thoracis muscle of each rib was isolated and cut in homogeneous portions and presented to 8 to 10 trained tasters isolated in booths. Each taster scored from 1 to 10 the intensity of the following characteristics: tenderness, juiciness and cardboard, metal, blood, milk, fat and grass flavours. Flavour variables used were selected by tasters in previous training sessions as the most important parameters to characterise young bull meat. Only a comparison of $\mathrm{HH}, \mathrm{GH}$ and $\mathrm{CP}$ groups was conducted.

\section{Statistical analysis}

Statistical analyses were performed using the GLM procedure (SAS, 1989). Feed intake, energy utilisation and muscle characteristics data corresponding to $\mathrm{HL}, \mathrm{HH}, \mathrm{GL}$ and $\mathrm{GH}$ groups were subjected to analysis of variance to examine the effect of forage type (grass $v$. hay) and concentrate level (high $v$. low) using a two-factor model $(2 \times 2)$. Interaction between the two factors was included in the model when significant. In a second step, the same information corresponding to $\mathrm{HL}, \mathrm{HH}, \mathrm{GL}, \mathrm{GH}$ and $\mathrm{CP}$ groups was compared using a one-factor ('group') model. Data corresponding to different muscles were analysed independently. Differences between means were separated by DUNCAN test. The results are presented as mean \pm s.e.

For other production results and carcass characteristics, statistical analysis were also performed in two steps: in the first step (for $\mathrm{HL}, \mathrm{HH}, \mathrm{GL}$ and $\mathrm{GH}$ groups), model included forage type and concentrate level as independent variables, their interaction and weight at turn-out to pasture as covariate variable; in the second step $(\mathrm{HL}, \mathrm{HH}, \mathrm{GL}, \mathrm{GH}$ and $\mathrm{CP}$ groups), model only included 'group' as independent variable and weight at turn-out to pasture as covariate. Forage type $\times$ concentrate level interaction was eliminated from the model when not significant $(P>0.1)$. Differences between means were separated by the PDIFF procedure of SAS. The results are presented as least-squared mean \pm s.e.

Variance analysis of sensory results was performed taking the effects of group and taster into consideration.

\section{Results}

Intake

Table 4 shows average daily intake of milk, concentrate and forage for all the experimental period $(151 \pm 14$ days, 
Serrano, Pradel, Jailler, Dubroeucq, Bauchart, Hocquette, Listrat, Agabriel and Micol

Table 4 Effect of forage type and concentrate level on voluntary intake and energy utilisation in $H L, H H, G L$ and GH groups ${ }^{\dagger}$

\begin{tabular}{|c|c|c|c|c|c|c|c|}
\hline & \multicolumn{4}{|c|}{ Group } & \multirow[b]{2}{*}{ s.e. } & \multicolumn{2}{|c|}{$P$ values } \\
\hline & $\mathrm{HL}$ & $\mathrm{HH}$ & $\mathrm{GL}$ & GH & & Forage type & Concentrate level \\
\hline Milk intake (kg/day) & 5.17 & 5.16 & 5.23 & 5.02 & 0.580 & 0.943 & 0.863 \\
\hline DM concentrate intake (kg/day) & $1.73^{\mathrm{b}}$ & $3.18^{\mathrm{a}}$ & $1.71^{\mathrm{b}}$ & $3.26^{\mathrm{a}}$ & 0.060 & 0.626 & 0.0001 \\
\hline DM forage intake (kg/day) & $2.26^{\mathrm{a}}$ & $1.41^{\mathrm{b}}$ & $2.55^{\mathrm{a}}$ & $1.24^{\mathrm{b}}$ & 0.298 & 0.843 & 0.003 \\
\hline Net energy intake (UFL/day) & $4.75^{\mathrm{c}}$ & $5.76^{\mathrm{ab}}$ & $5.40^{\mathrm{b}}$ & $5.96^{\mathrm{a}}$ & 0.210 & 0.065 & 0.003 \\
\hline PDI intake (g/day) & $482.5^{c}$ & $595.9^{\mathrm{ab}}$ & $560.5^{\mathrm{b}}$ & $623.3^{\mathrm{a}}$ & 21.43 & 0.029 & 0.001 \\
\hline Feed efficiency (live-weight gain (kg)/UFL) & 0.255 & 0.234 & 0.234 & 0.232 & 0.008 & 0.180 & 0.201 \\
\hline
\end{tabular}

a,b,c Means within a row with different superscripts differ significantly $(P<0.05)$.

${ }^{\dagger}$ Abbreviations are: $\mathrm{DM}=$ dry matter; $\mathrm{HL}=$ hay - low concentrate; $\mathrm{HH}=$ hay - high concentrate; $\mathrm{GL}=$ cut grass - low concentrate; $\mathrm{GH}=\mathrm{cut}$ grass - high concentrate; UFL = net energy for maintenance and gain expressed in milk feed units (Unités Fourragères Lait); PDI = protein truly digestible in the small intestine.
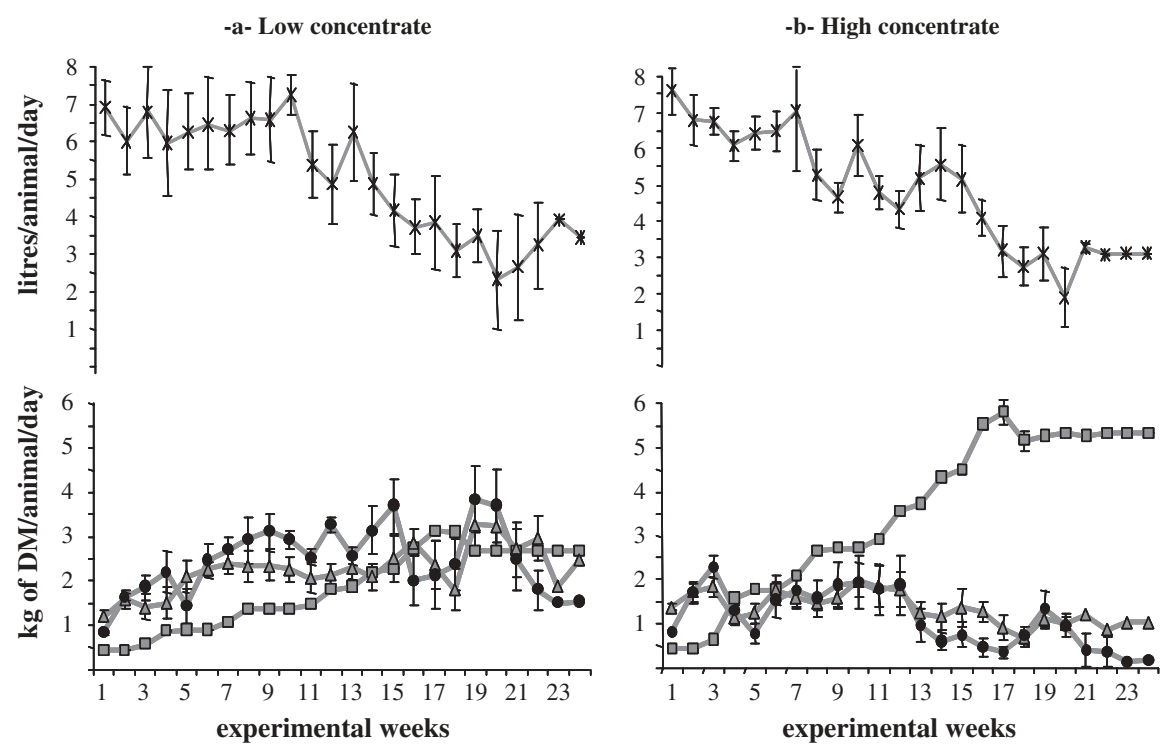

Figure 1 Milk $(\boldsymbol{X})$ ), concentrate $(\square-\square)$, hay $(\triangle-)$ and grass ( turn-out on pasture to slaughter. ( $\mathrm{DM}=$ dry matter).

between turn-out to pasture and slaughter). Figure 1 represents weekly intake of milk, concentrate, hay and grass in $\mathrm{HL}$ and $\mathrm{GL}$ groups (Figure 1a - low concentrate) and in $\mathrm{HH}$ and $\mathrm{GH}$ groups (Figure $1 \mathrm{~b}-$ high concentrate).

Total milk drunk was not different between $\mathrm{HL}, \mathrm{HH}, \mathrm{GL}$ and $\mathrm{GH}$ groups. DM concentrate intake in high-concentrate groups ( $\mathrm{HH}$ and $\mathrm{GH}$ ) increased from $0.5 \mathrm{~kg} /$ day to approximately $5.5 \mathrm{~kg} /$ day (Figure $1 \mathrm{~b}$ ) and was, as expected, almost twice as much of that of $\mathrm{HL}$ and GL groups. Average daily forage intake in low-concentrate groups was, approximately 1.8 times that of the high-concentrate groups (Table 4). Forage type had no effect on forage intake considering daily average values for the whole experimental period. But as illustrated in Figure $1 \mathrm{~b}$, concentrate substitution effect was higher in grass than in hay groups after the 13th experimental week.

Net energy intake tended to be affected by forage type $(P=0.06)$ and by concentrate intake level $(P=0.003)$. PDI (protein truly digestible in the small intestine) intake was affected by forage type $(P=0.03)$ and by concentrate intake level $(P=0.001)$. Values in $\mathrm{HL}$ group were lower than those in the other groups $(P<0.05)$ reflecting the lower feeding value of hay. Net energy and PDI intake values in $\mathrm{GH}$ group were higher than that in $\mathrm{GL}$ group $(P<0.05)$, and those of $\mathrm{HH}$ group were intermediate between those in $\mathrm{GL}$ and $\mathrm{GH}$ groups and not significantly different from these $(P>0.05)$.

Average total concentrate intake of $\mathrm{CP}$ group was $377 \mathrm{~kg}$, approximately $17 \%$ and $23 \%$ lower than in $\mathrm{HH}$ and $\mathrm{GH}$ groups. Mean values for total and daily milk intake tended to be higher ( $P=0.07$ and $P=0.08$, respectively) in CP group than in the others groups $(942 \pm 146 \mathrm{~kg}$ and $5.86 \pm 0.73 \mathrm{~kg} / \mathrm{day})$.

Growth, carcass yield and carcass composition Initial live weight (at turn-out to pasture, $141 \pm 9$ days of age) was on average $166 \pm 9 \mathrm{~kg}$. Age at slaughter was not 
different between groups $(286,290,291,296$ and $293 \pm 6$ days for groups $\mathrm{HL}, \mathrm{HH}, \mathrm{GL}, \mathrm{GH}$ and $\mathrm{CP}$, respectively).

Average daily weight gain (ADWG) in CP group (1542 g/ day) was significantly higher than that in the other four groups $(P<0.05)$. This group also had the highest live weight at slaughter (LWS), empty body weight (EBW) and carcass weight $(395,348$ and $230 \mathrm{~kg}$, respectively). However, significant differences were found only with $\mathrm{HL}$ group $(P<0.05)$ for EBW. LWS values of CP group tended to be higher than those of $\mathrm{HL}, \mathrm{HH}$ and $\mathrm{GL}$ groups $(P<0.1)$. Carcass weight of $C P$ group tended to be higher than those of $\mathrm{HL}$ and $\mathrm{GL}$ groups $(P<0.1)$. Dressing percentage in $\mathrm{CP}$ group was significantly higher $(P<0.05)$ than in the rest of experimental groups $(66.2 \%$ and $64.2 \%$ for $\mathrm{CP}$ v. HL, HH, $\mathrm{GL}$ and $\mathrm{GH}$ groups, respectively).

ADWG tended to be higher $(P=0.09)$ in high-concentrate groups than in low-concentrate groups (1248 and 1354 g/day for HL and GL v. HH and GH groups, respectively). Forage type did not affect ADWG (Table 5).

Concentrate level affected EBW $(P=0.05)$. Carcass weight tended to be higher $(P=0.07)$ in high-concentrate groups than in low-concentrate groups. After $C P$ animals, $\mathrm{GH}$ presented the highest EBW and carcass weight values (334 and $216 \mathrm{~kg}$, respectively) followed by HH (331 and $212 \mathrm{~kg}), \mathrm{GL}(312$ and $200 \mathrm{~kg}$ ) and $\mathrm{HL}(308$ and $198 \mathrm{~kg})$ groups, in this order. Differences tended to be significant $(P<0.1)$ only for EBW between $\mathrm{GH}$ and $\mathrm{HL}$ groups.

Concentrate level significantly affected carcass muscle weight $(P=0.04)$. GH bulls were heavier than $\mathrm{HL}$ and $\mathrm{GL}$ bulls $(155,141$ and $142 \mathrm{~kg}$, respectively; $P<0.05)$. Carcass fatty tissue was not affected by either of the two experimental factors, forage type - concentrate level. Carcass muscle weight in CP group (average $165 \mathrm{~kg}$ ) was higher $(P<0.05)$ than $\mathrm{HL}$ and $\mathrm{GL}$ groups. Offal fatty tissues weight, carcass fatness and conformation scores did not differ between groups (Table 5).

\section{Muscle characteristics}

Colour and $\mathrm{pH}$. Muscle $\mathrm{pH}$ (Table 6) was not affected by forage type or concentrate level. All animals obtained the maximal value $(4=$ red) of carcass lean colour score. The $C P$ group had higher $b^{*}$ values than $\mathrm{HL}$ and $\mathrm{HH}$ groups $(P<0.05)$.

Histological and enzymatic characteristics. Table 7 presents muscle fibre areas and enzyme activities for RA and ST muscles. Whatever the muscle, neither the type of forage nor the concentrate level affected the cross-sectional areas or metabolic enzyme activities of muscle fibres. CP group exhibited the highest values of muscle fibre area for ST muscle but 'group' factor was not significant. When comparing the five experimental groups, 'group' factor tended to be significant for CS enzyme activity $(P=0.06)$ in ST muscle. The highest values corresponded to $\mathrm{CP}$ group but differences were significant $(P<0.05)$ only when comparing $\mathrm{CP} v$. $\mathrm{HH}$ and $\mathrm{GL}$ groups.

Total and heat-soluble collagen. Neither total collagen content nor insoluble collagen content were affected by forage type or concentrate level factors (Figure 2). Similarly, when comparing the five experimental groups, 'group' factor was not significant. However, quality of collagen estimated by soluble/total collagen ratio was significantly affected by forage type $(P=0.03)$. Collagen solubility was lower in $\mathrm{HH}$ group than the other three groups $(P<0.05)$. When comparing the five experimental groups, 'group' factor was significant $(P=0.01)$. The highest collagen

Table 5 Average daily weight gain, weight at slaughter and carcass characteristics in five experimental groups $(H L, H H, G L, G H, C P)$ and effect of forage type and concentrate level ${ }^{t}$

\begin{tabular}{|c|c|c|c|c|c|c|c|c|c|c|c|c|}
\hline & \multicolumn{8}{|c|}{ Five group comparison } & \multicolumn{4}{|c|}{ Forage type + concentrate level comparison } \\
\hline & \multirow[b]{2}{*}{$\mathrm{HL}$} & \multirow[b]{2}{*}{$\mathrm{HH}$} & \multirow[b]{2}{*}{$\mathrm{GL}$} & \multirow[b]{2}{*}{$\mathrm{GH}$} & \multirow[b]{2}{*}{$\mathrm{CP}$} & \multirow[b]{2}{*}{ s.e. } & \multicolumn{2}{|r|}{$P$ values } & \multirow[b]{2}{*}{ s.e. } & \multicolumn{3}{|c|}{$P$ values } \\
\hline & & & & & & & Group & Initial weight & & $\mathrm{F}$ & $\mathrm{C}$ & Initial weight \\
\hline Live weight at slaughter $(\mathrm{kg})$ & $349.8^{d}$ & $359.5^{d}$ & $354.0^{\mathrm{d}}$ & $373.2^{\mathrm{cd}}$ & $394.7^{c}$ & 9.5 & 0.028 & 0.013 & 8.6 & 0.321 & 0.125 & 0.037 \\
\hline Average daily weight gain (g/day) & $1232^{\mathrm{b}}$ & $1340^{\mathrm{b}}$ & $1264^{\mathrm{b}}$ & $1368^{\mathrm{b}}$ & $1542^{\mathrm{a}}$ & 55 & 0.011 & 0.017 & 56 & 0.606 & 0.091 & 0.076 \\
\hline Empty body weight $(\mathrm{kg})$ & $307.9^{b}$ & $331.1^{\mathrm{ab}}$ & $312.2^{\mathrm{ab}}$ & $334.0^{\mathrm{a}}$ & $347.8^{\mathrm{a}}$ & 10.9 & 0.110 & 0.056 & 9.9 & 0.730 & 0.048 & 0.093 \\
\hline Warm carcass weight $(\mathrm{kg})$ & $197.8^{d}$ & $211.7^{\mathrm{cd}}$ & $200.2^{d}$ & $215.6^{\text {cd }}$ & $230.4^{c}$ & 7.9 & 0.069 & 0.065 & 7.1 & 0.673 & 0.068 & 0.142 \\
\hline Dressing percentage & $64.3^{\mathrm{b}}$ & $63.9^{\mathrm{b}}$ & $64.1^{b}$ & $64.5^{\mathrm{b}}$ & $66.2^{\mathrm{a}}$ & 0.50 & 0.036 & 0.513 & 0.48 & 0.672 & 0.998 & 0.837 \\
\hline \multicolumn{13}{|l|}{ Carcass composition: } \\
\hline Muscle weight $(\mathrm{kg})$ & $140.8^{b}$ & $151.7^{\mathrm{ab}}$ & $141.6^{\mathrm{b}}$ & $154.5^{\mathrm{a}}$ & $164.8^{\mathrm{a}}$ & 5.9 & 0.070 & 0.112 & 5.1 & 0.737 & 0.044 & 0.278 \\
\hline Fatty tissue weight $(\mathrm{kg})$ & 21.7 & 22.7 & 23.2 & 24.0 & 24.0 & 1.2 & 0.145 & 0.070 & 1.2 & 0.248 & 0.452 & 0.043 \\
\hline Bone weight $(\mathrm{kg})$ & 35.3 & 37.2 & 35.3 & 37.1 & 39.6 & 1.2 & 0.113 & 0.011 & 1.2 & 0.948 & 0.156 & 0.036 \\
\hline Offal fatty tissue $(\mathrm{kg})$ & 7.39 & 9.65 & 9.09 & 9.50 & 9.61 & 1.10 & 0.588 & 0.638 & 0.93 & 0.473 & 0.226 & 0.765 \\
\hline Offal fatty tissue/EBW (\%) & 2.39 & 2.91 & 2.91 & 2.84 & 2.75 & 0.27 & 0.650 & 0.241 & 0.24 & 0.401 & 0.457 & 0.830 \\
\hline Total fatty tissue $(\mathrm{kg})$ & 29.2 & 32.3 & 32.3 & 33.4 & 35.7 & 2.1 & 0.324 & 0.419 & 1.9 & 0.299 & 0.302 & 0.156 \\
\hline Fatness score & 2.23 & 2.13 & 2.25 & 2.13 & 2.12 & 0.16 & 0.954 & 0.919 & 0.12 & 0.960 & 0.545 & 0.657 \\
\hline Conformation score & 5.57 & 5.57 & 5.76 & 6.85 & 7.16 & 0.54 & 0.160 & 0.026 & 0.50 & 0.217 & 0.357 & 0.113 \\
\hline
\end{tabular}

a,b Means within a row with different superscripts differ significantly $(P<0.05)$.

${ }^{c, d}$ Means within a row with different superscripts tended to differ significantly $(P<0.1)$.

${ }^{+}$Abbreviations are: $\mathrm{HL}=$ hay - low concentrate; $\mathrm{HH}=$ hay - high concentrate; $\mathrm{GL}=$ cut grass - low concentrate; $\mathrm{GH}=$ cut grass - high concentrate; $\mathrm{CP}=$ control pasture; $\mathrm{F}=$ forage type; $\mathrm{C}=$ concentrate level; $\mathrm{EBW}=$ empty body weight. 
Serrano, Pradel, Jailler, Dubroeucq, Bauchart, Hocquette, Listrat, Agabriel and Micol

Table $6 \mathrm{pH}$ and colour parameters values in five experimental groups (HL, HH, GL, GH, CP) and effect of forage type and concentrate level in theses variables of rectus abdominis and semitendinosus muscles ${ }^{t}$

\begin{tabular}{|c|c|c|c|c|c|c|c|c|c|c|}
\hline & \multicolumn{7}{|c|}{ Five group comparison } & \multicolumn{3}{|c|}{ Forage type + concentrate level comparison } \\
\hline & \multirow[b]{2}{*}{$\mathrm{HL}$} & \multirow[b]{2}{*}{$\mathrm{HH}$} & \multirow[b]{2}{*}{ GL } & \multirow[b]{2}{*}{$\mathrm{GH}$} & \multirow[b]{2}{*}{$\mathrm{CP}$} & \multirow[b]{2}{*}{ s.e. } & \multirow{2}{*}{$\begin{array}{l}P \text { value } \\
\text { Group }\end{array}$} & \multirow[b]{2}{*}{ s.e. } & \multicolumn{2}{|c|}{$P$ values } \\
\hline & & & & & & & & & $\mathrm{F}$ & $C$ \\
\hline \multicolumn{11}{|c|}{ Rectus abdominis muscle } \\
\hline $\mathrm{pH} 24 \mathrm{~h}$ & 5.78 & 5.76 & 5.87 & 5.74 & 5.72 & 0.05 & 0.400 & 0.06 & 0.581 & 0.254 \\
\hline$L^{*}$ & 36.75 & 35.38 & 36.08 & 36.36 & 31.40 & 1.62 & 0.182 & 1.80 & 0.933 & 0.770 \\
\hline$a^{*}$ & 8.35 & 7.01 & 8.12 & 7.34 & 11.0 & 1.14 & 0.164 & 1.22 & 0.967 & 0.405 \\
\hline$b^{*}$ & $9.87^{b}$ & $8.73^{b}$ & $12.06^{\mathrm{ab}}$ & $10.55^{\mathrm{ab}}$ & $14.04^{\mathrm{a}}$ & 1.21 & 0.058 & 1.31 & 0.154 & 0.333 \\
\hline \multicolumn{11}{|c|}{ Semitendinosus muscle } \\
\hline $\mathrm{pH} 24 \mathrm{~h}$ & 5.65 & 5.73 & 5.70 & 5.72 & 5.72 & 0.04 & 0.299 & 0.05 & 0.661 & 0.300 \\
\hline $\mathrm{L}^{*}$ & 37.81 & 37.81 & 37.94 & 35.38 & 35.27 & 1.45 & 0.480 & 1.56 & 0.477 & 0.428 \\
\hline$a^{*}$ & 8.73 & 7.61 & 8.19 & 8.37 & 8.79 & 0.83 & 0.854 & 0.85 & 0.901 & 0.588 \\
\hline$b^{*}$ & $12.34^{\mathrm{b}}$ & $12.58^{\mathrm{b}}$ & $13.32^{\mathrm{ab}}$ & $13.10^{\mathrm{ab}}$ & $14.80^{\mathrm{a}}$ & 0.55 & 0.053 & 0.50 & 0.164 & 0.983 \\
\hline
\end{tabular}

$\overline{a, b}$ Means within a row with different superscripts differ significantly $(P<0.05)$.

${ }^{\dagger}$ Abbreviations are: $\mathrm{HL}=$ hay - low concentrate; $\mathrm{HH}=$ hay - high concentrate; $\mathrm{GL}=$ cut grass - low concentrate; $\mathrm{GH}=$ cut grass - high concentrate; $\mathrm{CP}=$ control pasture; $\mathrm{F}=$ forage type; $\mathrm{C}=$ concentrate level.

Table 7 Fibre area and LDH, PFK, ICDH, CS and COX enzyme activities in five experimental groups (HL, HH, GL, GH, CP) and effect of forage type and concentrate levelt

\begin{tabular}{|c|c|c|c|c|c|c|c|c|c|c|c|}
\hline & \multicolumn{7}{|c|}{ Five group comparison } & \multicolumn{4}{|c|}{ Forage type + concentrate level comparison } \\
\hline & \multirow[b]{2}{*}{$\mathrm{HL}$} & \multirow[b]{2}{*}{$\mathrm{HH}$} & \multirow[b]{2}{*}{$\mathrm{GL}$} & \multirow[b]{2}{*}{$\mathrm{GH}$} & \multirow[b]{2}{*}{$\mathrm{CP}$} & \multirow[b]{2}{*}{ s.e. } & \multirow{2}{*}{$\frac{P \text { values }}{\text { Group }}$} & \multirow[b]{2}{*}{ s.e. } & \multicolumn{3}{|c|}{$P$ values } \\
\hline & & & & & & & & & $\mathrm{F}$ & $\mathrm{C}$ & $\mathrm{F} \times \mathrm{C}$ \\
\hline \multicolumn{12}{|l|}{ Rectus abdominis muscle } \\
\hline Fibre area $\left(\mu \mathrm{m}^{2}\right)$ & 2168 & 2541 & 2149 & 2203 & 2240 & 233 & 0.753 & 252 & 0.493 & 0.413 & \\
\hline $\mathrm{LDH}(\mu \mathrm{mol} / \mathrm{min}$ per $\mathrm{g})$ & 841.2 & 883.7 & 811.2 & 908.1 & 866.6 & 50.8 & 0.708 & 52.4 & 0.966 & 0.212 & \\
\hline PFK $(\mu \mathrm{mol} / \mathrm{min}$ per $\mathrm{g})$ & 123.9 & 105.6 & 115.2 & 124.1 & 96.6 & 9.5 & 0.228 & 8.8 & 0.555 & 0.571 & \\
\hline $\mathrm{ICDH}(\mu \mathrm{mol} / \mathrm{min}$ per $\mathrm{g})$ & 1.32 & 1.52 & 1.41 & 1.24 & 1.54 & 0.13 & 0.450 & 0.12 & 0.482 & 0.930 & \\
\hline $\mathrm{CS}(\mu \mathrm{mol} / \mathrm{min}$ per $\mathrm{g})$ & 4.40 & 6.04 & 5.92 & 4.96 & 5.86 & 0.56 & 0.206 & 0.51 & 0.673 & 0.521 & 0.027 \\
\hline $\begin{array}{l}\text { COX ( } \mu \text { mol cytochrome } \\
\text { c/min per } \mathrm{g} \text { ) }\end{array}$ & 14.38 & 15.73 & 13.54 & 11.70 & 17.57 & 2.24 & 0.447 & 2.0 & 0.246 & 0.904 & \\
\hline \multicolumn{12}{|l|}{ Semitendinosus muscle } \\
\hline Fibre area $\left(\mu \mathrm{m}^{2}\right)$ & 2569 & 2333 & 2147 & 2615 & 3163 & 253 & 0.108 & 277 & 0.805 & 0.683 & \\
\hline $\mathrm{LDH}(\mu \mathrm{mol} / \mathrm{min}$ per $\mathrm{g})$ & 895.4 & 843.0 & 900.2 & 913.2 & 867.7 & 60.2 & 0.923 & 62.0 & 0.557 & 0.757 & \\
\hline $\mathrm{PFK}(\mu \mathrm{mol} / \mathrm{min}$ per $\mathrm{g})$ & 137.8 & 129.7 & 126.5 & 126.2 & 117.1 & 9.4 & 0.653 & 9.9 & 0.472 & 0.701 & \\
\hline $\mathrm{ICDH}(\mu \mathrm{mol} / \mathrm{min}$ per $\mathrm{g})$ & 1.90 & 2.33 & 1.51 & 1.76 & 1.91 & 0.60 & 0.910 & 0.65 & 0.476 & 0.609 & \\
\hline $\mathrm{CS}(\mu \mathrm{mol} / \mathrm{min}$ per $\mathrm{g})$ & $6.40^{\mathrm{ab}}$ & $5.30^{b}$ & $4.52^{b}$ & $6.67^{a b}$ & $8.10^{\mathrm{a}}$ & 0.81 & 0.064 & 0.90 & 0.784 & 0.568 & 0.096 \\
\hline $\begin{array}{l}\text { COX ( } \mu \text { mol cytochrome } \\
\mathrm{c} / \text { min per } \mathrm{g} \text { ) }\end{array}$ & 11.76 & 16.23 & 12.70 & 16.23 & 14.60 & 2.24 & 0.529 & 2.47 & 0.853 & 0.132 & \\
\hline
\end{tabular}

a,b Means within a row with different superscripts significantly differ $(P<0.05)$.

${ }^{+}$Abbreviations are: $\mathrm{LDH}=$ lactate dehydrogenase; PFK = phosphofructokinase; ICDH = isocitrate dehydrogenase; CS = citrate synthase; COX = cytochrome-C oxidase $\mathrm{HL}=$ hay - low concentrate; $\mathrm{HH}=$ hay - high concentrate; $\mathrm{GL}=$ cut grass - low concentrate; $\mathrm{GH}=$ cut grass - high concentrate; $\mathrm{CP}=$ control pasture; $\mathrm{F}=$ forage type; $\mathrm{C}=$ concentrate level; $\mathrm{LDH}=$ lactate dehydrogenase; $\mathrm{PFK}=$ phosphofructokinase; ICDH = isocitrate dehydrogenase.

solubility was found in CP group, in which it was significantly higher $(P=0.05)$ than in $\mathrm{HL}$ and $\mathrm{HH}$ groups.

Lipid content. Table 8 presents total lipid content and fatty acid composition of RA muscle. The lipid content of RA muscle was relatively low (on average $68.7 \mathrm{mg} / \mathrm{g} \mathrm{DM}$ ) and was not affected by feeding treatments $(P>0.05)$. Percentages of monounsaturated fatty acids were lower in hayfed than in grass-fed animals $(P=0.05)$. Percentages of polyunsaturated fatty acids (PUFA) were higher in hay-fed animals but differences were not significant. The ratio between $n-6 / n-3$ PUFA was lower $(P=0.01)$ in low-concentrate-fed groups than in high-concentrate-fed groups. 

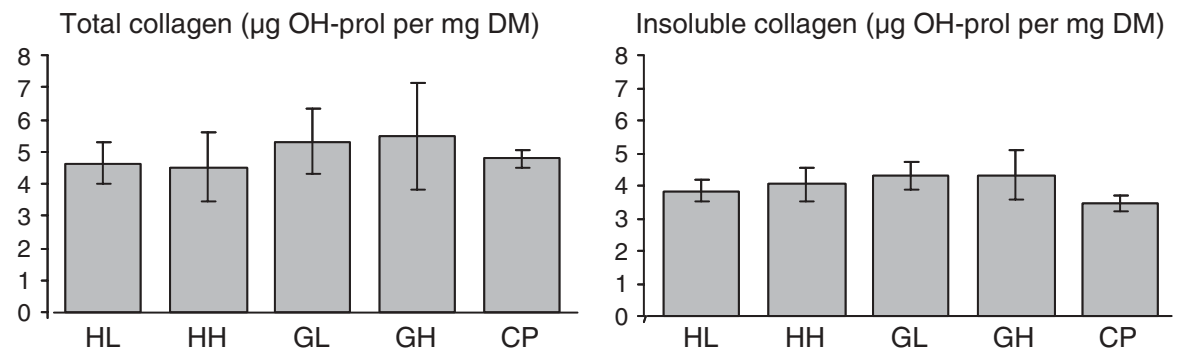

Soluble collagen / Total collagen (\%)

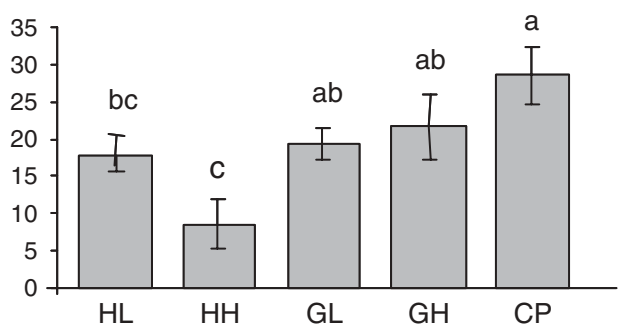

Figure 2 Total and insoluble collagen content, and collagen solubility of rectus abdominis muscle in five experimental groups (a-c = means with different letters significantly differ at $\mathrm{P}<0.05 ; \mathrm{OH}$-prol = hydroxy proline; $\mathrm{DM}=$ dry matter; $\mathrm{HL}=$ hay - low concentrate; $\mathrm{HH}=$ hay - high concentrate; $\mathrm{GL}=\mathrm{cut}$ grass - low concentrate; $\mathrm{GH}=$ cut grass - high concentrate; $\mathrm{CP}=$ control pasture).

Table 8 Effect of forage type and concentrate level in five experimental groups (HL, HH, GL, GH, CP) on lipid content and FA composition of rectus abdominis muscle ${ }^{t}$

\begin{tabular}{|c|c|c|c|c|c|c|c|c|c|c|}
\hline & \multicolumn{7}{|c|}{ Five group comparison } & \multicolumn{3}{|c|}{ Forage type + concentrate level comparison } \\
\hline & \multirow[b]{2}{*}{$\mathrm{HL}$} & \multirow[b]{2}{*}{$\mathrm{HH}$} & \multirow[b]{2}{*}{$\mathrm{GL}$} & \multirow[b]{2}{*}{$\mathrm{GH}$} & \multirow[b]{2}{*}{$\mathrm{CP}$} & \multirow[b]{2}{*}{ s.e. } & \multirow{2}{*}{$\frac{P \text { values }}{\text { Group }}$} & \multirow[b]{2}{*}{ s.e. } & \multicolumn{2}{|c|}{$P$ values } \\
\hline & & & & & & & & & $\mathrm{F}$ & C \\
\hline Total lipids (mg/g dry matter) & 74.6 & 63.5 & 70.0 & 66.5 & 63.0 & 7.2 & 0.768 & 7.9 & 0.918 & 0.376 \\
\hline In $\%$ of total FA & & & & & & & & & & \\
\hline$\sum$ Saturated $\mathrm{FA}^{\top}$ & 47.7 & 48.3 & 46.6 & 49.4 & 49.1 & 2.3 & 0.909 & 2.5 & 0.990 & 0.489 \\
\hline$\sum$ Monounsaturated FA & 31.9 & 28.9 & 33.5 & 32.9 & 31.2 & 1.2 & 0.112 & 1.3 & 0.051 & 0.191 \\
\hline$\sum P^{2}$ & 14.2 & 16.2 & 13.1 & 12.3 & 13.6 & 1.5 & 0.488 & 1.5 & 0.141 & 0.732 \\
\hline$(n-6)$ PUFA $^{\ddagger} /(n-3)$ PUFA $^{\S}$ & $4.25^{b}$ & $5.05^{a b}$ & $3.64^{\mathrm{b}}$ & $5.69^{a}$ & $4.40^{\mathrm{ab}}$ & 0.45 & 0.045 & 0.47 & 0.975 & 0.011 \\
\hline$(n-6)+(n-3)$ PUFA/linear saturated FA" & 0.32 & 0.36 & 0.29 & 0.26 & 0.29 & 0.04 & 0.624 & 0.05 & 0.205 & 0.938 \\
\hline
\end{tabular}

${ }^{\mathrm{a}, \mathrm{b}}$ Means within a row with different superscripts differ significantly $(P<0.05)$.

${ }^{+}$Abbreviations are: $\mathrm{F}=$ forage type; $\mathrm{C}=$ concentrate level; $\mathrm{HL}=$ hay - low concentrate; $\mathrm{HH}=$ hay - high concentrate; $\mathrm{GL}=$ cut grass - low concentrate; $\mathrm{GH}=$ cut grass - high concentrate; $\mathrm{CP}=$ control pasture; $\mathrm{FA}=$ fatty acid; PUFA = polyunsaturated fatty acid.

'Saturated FA = sum of total linear and total branched chain saturated FA. Monounsaturated FA = sum of total 16:1 cis and trans isomers, total 18:1 cis and trans isomers, C20:1 cis, C22:1 cis and C24:1 cis fatty acids. PUFA = sum of $(n-6)$ PUFA and $(n-3)$ PUFA.

${ }^{\ddagger}(n-6)$ PUFA $=$ sum of C18:2 n-6, C18:3 n-6, C20:2 n-6, C20:3 n-6, C20:4 n-6, C22:2 n-6, C22:4 n-6 fatty acids.

$\S(n-3)$ PUFA $=$ sum of C18:3 n-3, C20:3 n-3, C18:4 n-3, C20:5 n-3, C22:5 n-3 and C22:6 n-3 fatty acids.

"Linear saturated FA = sum of C10:0, C11:0, C12:0, C13:0, C14:0, C15:0, C16:0, C17:0, C18:0, C20:0, C21:0, C22:0, C23:0 and C24:0 fatty acids.

Mean $n-6 / n-3$ ratio in CP group (4.40) was intermediate between the highest values corresponding to $\mathrm{HH}$ and $\mathrm{GH}$ groups and the lowest values corresponding to $\mathrm{HL}$ and $\mathrm{GL}$ groups. Differences were significant $(P<0.05)$ only when $\mathrm{GH} v$. HL and GL groups were compared.

Muscle sensory traits. Table 9 presents the results for the taste panel scores in longissimus thoracis corresponding for groups CP, HH and GH. 'Group' factor was significant only for tenderness and juiciness variables $(P=0.01$ and
$P=0.003$, respectively). CP group presented significantly lower tenderness and juiciness values $(P<0.05)$ than $\mathrm{HH}$ and GH groups.

\section{Discussion}

The production system adapted resulted in the production of relatively lean carcasses averaging $210 \mathrm{~kg}$. Highconcentrate-fed groups presented slightly higher ADWG than low-concentrate-fed groups (approximately $100 \mathrm{~g}$ ). 
Serrano, Pradel, Jailler, Dubroeucq, Bauchart, Hocquette, Listrat, Agabriel and Micol

Table 9 Meat sensory traits in longissimus thoracis muscle of $H H, G H$ and $C P$ groups $^{+}$

\begin{tabular}{lccccccc}
\hline \hline & \multicolumn{3}{c}{ Group } & & \multicolumn{2}{c}{$P$ values } \\
\cline { 2 - 3 } & HH & GH & CP & s.e. & Group & Taster \\
\hline Tenderness & $5.17^{\mathrm{a}}$ & $5.42^{\mathrm{a}}$ & $4.14^{\mathrm{b}}$ & 0.96 & 0.01 & 0.004 \\
$\begin{array}{l}\text { Juiciness } \\
\text { Flavours }\end{array}$ & $4.60^{\mathrm{a}}$ & $4.79^{\mathrm{a}}$ & $3.63^{\mathrm{b}}$ & 0.75 & 0.003 & $<0.0001$ \\
$\quad$ & & & & & & \\
$\quad$ Cardboard & 1.55 & 1.43 & 1.77 & 0.49 & 0.33 & $<0.0001$ \\
$\quad$ Metal & 1.48 & 1.43 & 1.48 & 0.67 & 0.98 & $<0.0001$ \\
Blood & 1.59 & 1.11 & 1.16 & 0.67 & 0.25 & $<0.0001$ \\
Milk & 0.87 & 1.07 & 1.01 & 0.41 & 0.57 & $<0.0001$ \\
Fat & 0.88 & 1.00 & 0.96 & 0.65 & 0.92 & $<0.0001$ \\
$\quad$ Grass & 0.87 & 0.93 & 1.06 & 0.49 & 0.72 & $<0.0001$ \\
\hline \hline
\end{tabular}

${ }^{a, b}$ Means within a row with different superscripts differ significantly $(P<0.05)$.

${ }^{+}$Abbreviations are: $\mathrm{HH}=$ hay - high concentrate; $\mathrm{GH}=$ cut grass - high concentrate; $\mathrm{CP}=$ control pasture.

High-concentrate feeding increased carcass weight by $15 \mathrm{~kg}$ compared with low-concentrate feeding. Differences in ADWG between high-concentrate and low-concentrate groups were expressed by differences in carcass weight associated with higher muscle weight but without differences in fatness. Carcass fatness is affected by several factors like sex, age, genotype and growth rate (Micol et al., 1993). Usually, higher growth rates are associated with higher carcass fatness, but many experiments that found this effect were performed with bulls slaughtered at higher ages than in the present work (Steen and Kilpatrick, 1995; Listrat et al., 1999; Sami et al., 2004) or with animals differing in sex (heifers or steers) and age (French et al., 2001). Sinclair et al. (1998) indeed observed significant differences in carcass weight but not in carcass fatness in young Charolais bulls slaughtered between 10 and 19 months, with daily gains differing on average by $600 \mathrm{~g} /$ day $(1.41 \mathrm{v} .1 .98 \mathrm{~kg} / \mathrm{day})$. In the same experiment, these authors obtained carcasses with the same weight but differing in fatness with bulls of a higher precocity genotype (Aberdeen Angus) differing by $300 \mathrm{~g} /$ day in growth rate (daily gains of 1.22 v. $1.55 \mathrm{~kg} /$ day).

Diet did not affect muscle $\mathrm{pH}$, which agrees with the observations from numerous studies (French et al., 2000 and 2001; Sami et al., 2004) and suggests that all diets supplied sufficient energy to allow a normal $\mathrm{pH}$ evolution. Muir et al. (1998) indicated that grass-fed animals often presented higher $\mathrm{pH}$ values than grain-fed animals as a result of interaction of diet and their higher susceptibility to pre-slaughter stress because they are less used to handling. In our study, animals were slaughtered within $4 \mathrm{~h}$ after removal from experimental installations and all groups were used to handling, which may have minimised the impact of stress on the depletion of glycogen deposits.

Muscle colour is an important criterion by which many consumers evaluate meat quality and acceptability. The results concerning subjective classification of muscle colour showed that an important characteristic of the meat pro- duced is that it was very red compared with traditional veal meat. Diet (forage type and concentrate level) had no effect on $L^{*}$ and $a^{*}$ colour parameters. In the two muscles that were considered, $b^{*}$ values were higher in grass-fed animals but differences were significant only when comparing pasture-fed $v$. hay-fed animals. Animals raised on pasture presented the lowest $L^{*}$ values compared with the other four groups of animals but differences were not significant. Meat from cattle raised on pasture is indeed known to be darker than meat from animals raised on concentrates (Priolo et al., 2001). But French et al. (2000 and 2001) did not observe any difference in colour parameters in steers finished (85 days) on diets constituting combinations of different forages (grass silage, grass or hay) and different concentrate levels allowing the same or different growth rates and slaughtered at the same age. Varela et al. (2004) also failed to find differences in meat colour between steers finished (3 months) exclusively on pasture or with corn silage and concentrate, slaughtered at the same age and live weight. On the contrary, Nuernberg et al. (2005) reported lower $L^{*}$ values $\left(a^{*}\right.$ and $b^{*}$ values were not measured) in bulls finished on grass-based $v$. concentratebased diets. These authors hypothesised that these differences could be associated with higher physical activity of grass-fed animals compared with indoor kept concentratefed bulls. It is, however, necessary to point out that in this work the experimental period (between 11 and 19 months) was longer and started when animals were younger than in the experiments cited before and pasture-finished animals were slaughtered at higher age than concentrate-fed ones (18 v. 24 months). In agreement with our observations, Monserrat et al. (2001) also noted higher $b^{*}$ values in pasture-fed than in concentrate-hay-fed young bull meat.

Neither forage type nor concentrate level affected muscle fibre area. These results are in accordance with those of Listrat et al. (1999) who did not find any difference in muscle fibre area between Salers bulls fed on isoenergetic and isoproteic diets based on grass silage or hay and concentrate. Cassar-Malek et al. (2004a), Maltin et al. (2001) and Sami et al. (2004) also failed to find differences in muscle fibre surface between animals finished on highor low-energy diets and presenting moderate differences in growth rates (between 200 and $400 \mathrm{~g} /$ day). In contrast with these observations, Jurie et al. (1999) showed that restricted growth rate was associated with lower fibre surface, but differences in growth rate observed in this latter experiment (approximately $640 \mathrm{~g} /$ day) were greater than differences observed in our study and in experiments cited before. It is interesting to note that in the ST muscle, the highest values of fibre size corresponded to pasture animals, although differences were not significant. In agreement with this observation, Jurie et al. (1998) observed an increase in ST muscle fibre size in animals housed in loose housing compared with those housed in tying-type housing.

Several works have reported the effect of diet on muscle energy metabolism. The results obtained in several studies suggested an association between grass or grass silage 
feeding and an increase in oxidative activities of muscles (Jurie et al., 1999; Listrat et al., 1999). In the present work, diet did not affect enzyme activities. This result agrees with observations of Maltin et al. (1998) who did not find differences in these parameters in young bulls fed on grasssilage-based or barley-based diets. However, we found higher CS enzyme activities in pasture-fed animals. This observation agrees with the results of Jurie et al. (2004) and Cassar-Malek et al. (2004b) who observed that in the development of muscle metabolic characteristics mobility is a much more important factor than diet. In agreement with our results, Jurie et al. (1998) observed that effects of physical activity on enzyme activities depended on type of muscle studied, or more precisely, the involvement of this muscle in movement (e.g. ST) or posture (e.g. RA).

Quantity and solubility of collagen may be influenced by several factors, including growth rate, nature of diet, physical activity and muscle analysed (Bailey and Light, 1989). We did not observe significant differences between groups in total and insoluble collagen contents of RA muscle but soluble/insoluble collagen content ratio was higher in the three grass-fed groups. Contradictions exist in the literature about effects of growth rate and diet nature on collagen pattern. Sami et al. (2004), comparing four diets based on different proportions of maize silage and concentrate formulated to allow different growth rates, did not find differences in collagen content but higher collagen solubility in animals with higher daily weight gain. Maltin et al. (1998) observed higher collagen content in longissimus lumborum muscle of animals finished on grass-silage-based diet having low growth rate than in animals finished on barleybased diet having high growth rate (approximate weight gain differences of $400 \mathrm{~g} /$ day) and no effect on collagen solubility. Listrat et al. (1999), comparing two groups of Salers bulls fed on diets based on grass silage or hay, did not observe differences in ST muscle collagen content. In this experiment, hay-fed animals presented lower growth rates and higher collagen solubility than grass-silage-fed animals $(-122 \mathrm{~g} /$ day).

Intramuscular fat content can be modified by several factors like age, genotype and growth rate. In general, intramuscular fat content increases with age and with growth rate and is higher in mixed breeds than in beef breeds (Nürnberg et al., 1998). In the present experiment, intramuscular fat content was not affected by production strategies and values obtained (between 15.1 and $17.7 \mathrm{mg} / \mathrm{g}$ wet matter muscle and between 63.0 and $74.6 \mathrm{mg} / \mathrm{g}$ dry muscle) were very low compared with those obtained in other works for longissimus thoracis muscle, in general a muscle less fatty than RA muscle analysed in the present work. These results could be explained by the moderate growth rates obtained and by the young age at slaughter. For example, Serra et al. (2004) reported mean values of intramuscular fat content of $24 \mathrm{mg} / \mathrm{g}$ wet muscle in Bruna dels Pirineus bulls slaughtered at 30 months. Varela et al. (2004) did not observe differences in intramuscular fat content between 33 months Rubia Gallega steers finished on pasture or on maize-silage-based and concentrate-based diets. These authors also obtained, for longissimus thoracis muscle, mean values of $27 \mathrm{mg}$ of total fat $/ \mathrm{g}$ wet muscle. Maltin et al. (1998) observed an important effect of age on intramuscular fat content but did not find differences between animals with growth rates differing between 300 and $600 \mathrm{~g} /$ day. They reported intramuscular fat content of $171.1 \mathrm{mg} / \mathrm{g}$ DM in Aberdeen Angus and Charolais bulls slaughtered at 11.5 months of age.

United Kingdom Department of Health recommends a polyunsaturated:saturated $(P / S)$ ratio $\sim 0.45$ in the whole diet of man, and increasing intake of $n-3$ relative to $n-6$ PUFA and achieving a $n-6 / n-3$ fatty acids ratio below 4.0 (Enser et al., 1998). Ruminant meats are known to have low polyunsaturated/saturated fatty acid ratio because of rumen biohydrogenation of dietary unsaturated fat (Geay et al., 2002). In the present experiment, production strategies did not affect P/S ratio. Hornick et al. (1996) showed that inclusion of milk in fattening diet of bulls increased saturated fatty acid content of intramuscular fat and decreased monounsaturated and polyunsaturated fatty acid contents. In our experiment, all animals remained unweaned until slaughter and, as in the experience of Hornick et al. (1997), closure of oesophageal groove remained active. P/S ratios in the present work were similar to those obtained by Varela et al. (2004) in Rubia Gallega steers, weaned at 9 months of age, maintained on pasture until 30 months of age and then finished for 3 months on concentrate or pasture systems (approximately 0.25 and 0.33 , respectively). However, P/S ratios were higher than those reported by Nuernberg et al. (2005) in Holstein and Simmental bulls slaughtered between 17 and 25 months of age and assigned to concentrate-based or grass-based production systems from weaning, at 6 months, to slaughter $(0.17$ and 0.21 for Holstein bulls and 0.20 and 0.32 for Simmental bulls). These results may, in part, be explained by the fact that when intramuscular fat content is low, as occurred in the present work, the relative importance of membrane phospholipids, rich in unsaturated fatty acids, is higher (Bas and Sauvant, 2001).

The $n-6 / n-3$ PUFA ratio in muscle fatty acids of ruminants is often too high relative to the recommendation noted above for man (Enser et al., 1998). Generally, muscles of grass-fed ruminants have lower $n-6$ PUFA and higher $n-3$ PUFA than concentrate-fed ruminants although adding sources of linoleic acid to concentrate (such as linseed) improves the equilibrium between these fatty acids in meat (Enser et al., 1998; Geay et al., 2002). In the present work, in agreement with the observations of Enser et al. (1998), Aurousseau et al. (2004) and Nuernberg et al. (2005) the more favourable values of $n-6 / n-3$ PUFA ratio corresponded to meat from animals fed on low concentrate and higher forage.

Higher growth rates have been associated with the production of more tender meat (French et al., 2001; Nuernberg et al., 2005). In the present work, pasturefed animals obtained significantly lower tenderness and 
juiciness scores than other groups, although they presented higher growth rates. Sami et al. (2004) and Sinclair et al. (2001) have not observed differences in tenderness of meat from 15 months bulls or steers, respectively, differing in growth rate. Listrat et al. (1999) obtained more tender meat in hay-fed Salers bulls than in grass-silage-fed animals having higher growth rates. Factors other than growth rate, such as diet composition (Listrat et al., 1999) or physical activity (Jurie et al., 1998), can affect the metabolic and histological characteristics of the muscle and, as a result, the meat tenderness. The results referring to metabolic and histological characteristics of the muscle indicated that pasture animals could have more oxidative muscles and could be constituted of fibres with larger surface than other groups. Several authors have associated these characteristics with tougher meat (Jurie et al., 1998; Renand et al., 2001) but not with a lower juiciness, more associated with other characteristics such as fat content (Geay et al., 2002). Differences in juiciness could be explained considering correlation between tenderness and juiciness scores $(r=0.46 ; P<0.0001)$, and that the pasture group presented the lowest mean value of fat content although values were not statistically different. Considering the importance of ageing process in quality of bovine meat coming from pasture systems (French et al., 2000; Renand et al., 2001), these results question whether the 8 days ageing period used was sufficient or not.

\section{Conclusion}

The results obtained suggest that the diets used have only a small effect on performance, offal fatty tissue weight, carcass and muscle characteristics and on meat eating quality traits. Meat produced was characterised by a very low fat content and a relatively high unsaturated fatty acid content, which could be favourable in a context of increased demand for leaner beef and consumer resistance to beef with a high fat content.

\section{Acknowledgements}

The authors wish, in particular, to thank I. Constant and C. Cirie for their help and support. The authors also thank Gloria López, INRA-Marcenat staff, M.C. Bayle, C2M and NEM staffs and the team of the experimental slaughterhouse in Theix.

\section{References}

Aurousseau B, Bauchart D, Calichon E, Micol D and Priolo A 2004. Effect of grass or concentrate feeding systems and rate of growth on triglyceride and phospholipid and their fatty acids in the $M$. longissimus thoracis of lambs. Meat Science 66, 531-541.

Bailey AJ and Light ND 1989. Connective tissue in meat and meat products. Elsevier Applied Science, London and New York.

Bas P and Sauvant D 2001. Variations de la composition des dépôts lipidiques chez les bovins. INRA Productions Animales 14, 311-322.

Beutler E 1971. Phosphofructokinase. In Red cell metabolism. A manual of biochemical methods (ed. E Beutler), pp. 42-44. Grune and Straton Inc., New York, USA.
Brandstetter AM, Picard B and Geay Y 1998. Muscle fibre characteristics in four muscles of growing male cattle. I. Postnatal differentiation. Livestock Production Science 53, 15-23.

Cassar-Malek I, Hocquette JF, Jurie C, Listrat A, Jailler R, Bauchart D, Briand D and Picard B 2004a. Muscle-specific metabolic, histochemical and biochemical responses to a nutritionally induced discontinuous growth path. Animal Science 79, 49-59.

Cassar-Malek I, Jurie C, Bernard C, Barnola I, Gentes G, Guivier N, Dozias D, Micol D and Hocquette JF 2004b. La conduite des bœufs au pâturage modifie les caractéristiques métaboliques des muscles et l'expression de certains gènes musculaires. Rencontres autour des Recherches sur les Ruminants 11, 124.

Chatellier V, Guyomard H and Le Bris K 2003. La production et les échanges de viande bovine dans le monde et dans I'Union européenne. INRA Productions Animales 16, 365-380.

Commission International de I'Eclairage 1986. Colorimetry, 2nd edition. CIE publication no. 15.2. Commission International de l'Eclairage, Vienna, Austria. D'Hour P, Petit M, Pradel P and Garel JP 1995. Evolution du poids de la production laitière au pâturage de vaches allaitantes Salers et Limousines dans deux milieux. Rencontres autour des Recherches sur les Ruminants 2, 105-108. D'Hour P, Petit M and Garel JP 1996. Effet de la conduite alimentaire sur le développement et l'âge à la puberté de génisses Limousines et Salers. Rencontres autour des Recherches sur les Ruminants 3, 233-236.

Enser M, Hallett KG, Hewett B, Fursey GAJ, Wood JD and Harrington G 1998. Fatty acid content and composition of UK beef and lamb muscle in relation to production system and implications for human nutrition. Meat Science 49, 329-341.

Folch J, Lees M and Stanley GHS 1957. A simple method for the isolation and purification of total lipids from animal tissue. Journal of Biological Chemistry 226, 497-509.

French P, O'Riordan EG, Monahan FJ, Caffrey PJ, Vidal M, Mooney MT, Troy DJ and Moloney AP 2000. Meat quality of steers finished on autumn grass, grass silage, or concentrate-based diets. Meat Science 56, 173-180.

French P, O'Riordan EG, Monahan FJ, Caffrey PJ, Mooney MT, Troy DJ and Moloney AP 2001. The eating quality of meat of steers fed grass and/or concentrates. Meat Science 57, 379-386.

Geay Y, Bauchart D, Hocquette JF and Culioli J 2002. Valeur diététique et qualitiés sensorielles des viandes de ruminants. Incidence de l'alimentation des animaux. INRA Productions Animales 15, 37-52.

Glass RL 1971. Alcoholysis, saponification and the preparation of fatty acid methyl esters. Lipids 6, 919-925.

Hornick JL, Clinquart A, Van Eenaeme C, Diez M and Istasse L 1996. Influence of whole milk in diet of growing fattening Belgian Blue bulls on animal performances and on fatty acid composition in subcutaneous, intermuscular and intramuscular fats. Livestock Production Science 48, 51-58.

Jurie C, Picard B and Geay Y 1998. Influences of the method of housing bulls on their body composition and muscle fibre types. Meat Science 50, 457-469.

Jurie C, Listrat A, Giraud X, Picard B, Geay Y and Hocquette JF 1999. Influence du niveau de croissance et de la nature de l'alimentation sur les caractéristiques musculaires de boeufs Charolais de 20 mois. Rencontres autour des Recherches sur les Ruminants 9, 259.

Jurie C, Ortigues-Marty I, Micol D, Cassar-Malek I, Dozias D, Picard B and Hocquette JF 2004. Effets respectifs de la nature de l'alimentation et de la mobilité sur le potentiel metabolique des muscles de boeufs charolais. Viandes et Produits Carnés (special issue), 71-72.

Le Neindre P 1973. Observations sur l'estimation de la production laitière des vaches allaitantes par la pesée du veau avant et après la tétée. Annales de Zootechnie 22, 413-422.

Liénard G, Lherm M, Pizaine MC, Le Maréchal JY, Boussange B, Barlet D, Esteve $P$ and Bouchy R 2002. Productivité de trois races bovines françaises, Limousine, Charolaise et Salers. INRA Productions Animales 15, 293-312.

Listrat A, Rakadjiyski N, Jurie C, Picard B, Touraille C and Geay Y 1999. Effect of the type of diet on muscle characteristics and meat palatability of growing Salers bulls. Meat Science 53, 115-124.

Listrat A, Picard B, Jailler R, Collignon H, Peccatte J-R, Micol D, Geay Y and Dozias D 2001. Grass valorisation and muscular characteristics of blonde d'Aquitaine steers. Animal Research 50, 105-118.

Maltin CA, Sinclair KD, Warris PD, Grant CM, Porter AD, Delday MI and Warkup CC 1998. The effects of age at slaughter, genotype and finishing system on the 
biochemical properties, muscle fibre type characteristics and eating quality of bull beef from suckled calves. Animal Science 66, 341-348.

Maltin CA, Lobley GE, Grant CM, Miller MA, Kyle DJ, Horgan GW, Matthews KR and Sinclair KD 2001. Factors influencing beef eating quality. 2. Effects of nutritional regimen and genotype on muscle fibre characteristics. Animal Science 72, 279-287.

Micol D, Robelin J and Geay Y 1993. Composition corporelle et caractéristiques biologiques des muscles chez les bovins en croissance et à l'engrais. INRA Productions Animales 6, 61-69.

Monserrat L, Sánchez L, Varela A, Carballo JA and Oliete B 2001. Producción de terneros de raza Rubia Gallega sacrificados sin destetar: efecto de la extensificación del manejo sobre el color de la carne y la grasa. ITEA 22 (volumen extra), 559-561.

Muir PD, Deaker JM and Brown MD 1998. Effects of forage and grain-based feeding systems on beef quality: a review. New Zealand Journal of Agricultural Research 41, 623-635.

Nuernberg K, Dannernberger D, Nuernberg G, Ender K, Voigt J, Scollan ND, Wood JD, Nute GR and Richardson RI 2005. Effect of a grass-based and a concentrate feeding system on meat quality characteristics and fatty acid composition of longissimus muscle in different cattle breeds. Livestock Production Science 94, 137-147.

Nürnberg K , Wegner J and Ender K 1998. Factors influencing fat composition in muscle and adipose tissue of farm animals. Livestock Production Science 56, 145-156.

Piot C, Veerkamp JH, Bauchart D and Hocquette JF 1998. Contribution of mitochondria and peroxisomes to palmitate oxidation in rat and bovine tissues. Comparative Biochemistry and Physiology. Part B: Biochemistry and Molecular Biology 121, 185-194.

Priolo A, Micol D and Agabriel J 2001. Effects of grass feeding systems on ruminant meat colour and flavour. A review. Animal Research 50, 185-200.
Renand G, Picard B, Touraille C, Berge P and Lepetit J 2001. Relationships between muscle characteristics and meat quality traits of young Charolais bulls. Meat Science 59, 49-60.

Robelin J and Geay Y 1975. Estimation de la composition de la carcasse des taurillons a partir de la composition de la $6^{\text {ème }}$ cote. Bulletin Technique CRZV de Theix, INRA 22, 41-44.

Sami AS, Augustini C and Schwarz FJ 2004. Effects of feeding intensity and time on feed on performance, carcass characteristics and meat quality of Simmental bulls. Meat Science 67, 195-201.

Statistical Analysis Systems Institute 1989. SAS/STAT ${ }^{\circledR}$ user's guide, version 6, 4th edition. SAS Institute Inc., Cary, NC, USA.

Serra X, Gil M, Gispert M, Guerrero L, Oliver MA, Sañudo C, Campo MM, Panea B, Olleta JL, Quintanilla R and Piedrafita J 2004. Characterisation of young bulls of the Bruna dels Pirineus cattle breed (selected from old Brown Swiss) in relation to carcass, meat quality and biochemical traits. Meat Science $66,425-436$

Sinclair KD, Cuthbertson A, Rutter A and Franklin MF 1998. The effects of age at slaughter, genotype and finishing system on the organoleptic properties and texture of bull beef from suckled calves. Animal Science 66, 329-340.

Sinclair KD, Lobley GE, Horgan GW, Kyle DJ, Porter AD, Matthews KR, Warkup CC and Maltin CA 2001. Factors influencing beef eating quality 1. Effects of nutritional regimen and genotype on organoleptic properties and instrumental texture. Animal Science 72, 269-277.

Steen RWJ and Kilpatrick DJ 1995. Effects of plane of nutrition and slaughter weight on the carcass composition of serially slaughtered bulls, steers and heifers of three breed crosses. Livestock Production Science 43, 205-213.

Varela A, Oliete B, Moreno T, Portela C, Monserrat L, Carballo JA and Sánchez $L$ 2004. Effect of pasture finishing on the meat characteristics and intramuscular fatty acid profile of steers of the Rubia Gallega breed. Meat Science 67, 515-522. 